\title{
Assessment of Evaporative Cooling System for Storage of Vegetables
}

\author{
B.G Jahun ${ }^{1}$, S.A. Abdulkadir², S. M. Musa ${ }^{3}$, Huzaifa Umar ${ }^{4}$ \\ ${ }^{1,3,4}$ Agricultural and Bioresource Engineering Department, Abubakar Tafawa Balewa University, Bauchi State, Nigeria \\ ${ }^{2}$ Agricultural and Bio-environmental Engineering Department, Adamawa State Polytechnic Yola, Adamawa State, Nigeria
}

\begin{abstract}
An evaporative cooler was developed and assessed with locally available materials. The materials were outsourced and constructed locally within the study area. A daily monitoring of temperature and relative humidity for both ambient and the cooler were recorded using the wet bulb and dry bulb thermometer and digital humidity-temperature meter. The weight loss was measured using a digital weighing balance. The performance of the evaporative cooler was evaluated in terms of drops in temperature, weight loss and increased relative humidity and evaporative effectiveness. From the results it showed that the evaporative cooler can lessen the daily maximum ambient temperature, the average temperature inside the cooling chamber varied from 20 to $23.5^{\circ} \mathrm{C}$ while the ambient air temperature varied from 25 to $28^{\circ} \mathrm{C}$ for tomatoes and an average of 20.5 to $26.5^{\circ} \mathrm{C}$ inside the cabinet while the ambient air temperature was from 28 to $30.5^{\circ} \mathrm{C}$ for hot pepper. The mean relative humidity of the cabinet during the period of the experiment was about 51 to 93\%, respectively, while the mean relative humidity of the ambient environment was from 47 to $58 \%$ for tomatoes, and the mean relative humidity for hot pepper was from 49 to $95 \%$ of the cabinet and the mean relative humidity of ambient was from 47 to $57 \%$. The effectiveness of the evaporative cooler was higher during the day between the periods of $12-14$ hrs.local time when observed. The evaporative cooler was able to preserve freshly harvested tomato and hot pepper for 8 days before color changes and mold spotting appeared and the weight was drastically reduced.
\end{abstract}

Keywords: Evaporative Cooler, Temperature, Relative humidity, Weight loss

\section{Introduction}

Vegetables are vital agricultural products for human consumption worldwide. They are rich in vitamins and minerals such as carotene (pro-vitamin A), ascorbic acid, riboflavin, iron, iodine, calcium etc. [1].

Vegetables are the fresh and edible portions of herbaceous plants. They are important food and highly beneficial for the maintenance of health and prevention of diseases. They contain valued food ingredients which can be successfully utilized to build up and repair the body. Vegetables are valuable in maintaining an alkaline reserve of the body. They are valued mainly for their high carbohydrate, vitamin and mineral contents from different kinds of vegetables [2].

The importance of fruits and vegetables is that they provide vitamins and other nutrients that help for proper function of the body. Fruits and vegetables are essential building blocks of any diet, not only they are loaded with vitamins and minerals which are essential for healthy living, but they also give satisfaction as part of the balanced diet [3].

Vegetables are generally regarded as an essential herbaceous plant with high moisture content in their fresh forms. They possess considerable quantities of vitamins $\mathrm{A}, \mathrm{B}, \mathrm{C}, \mathrm{D}, \mathrm{E}$ and $\mathrm{K}$, which help in protecting the body against diseases and contribute in no small measure to good health [3]. Hence, they provide maximum vitamins when consumed fresh.

Evaporative cooling has been found to be an efficient and economical means of reducing temperatures and increasing humidity in an enclosure where the humidity is comparatively low [4]. Minimizing deteriorative reactions in fruit and vegetables enhances their shelf lives, implying that the produce will be available for longer periods; this would reduce fluctuation in market supply and prices [5].

Fruits and vegetables are highly perishable commodities that cannot be kept for long period of time due to their perishable and seasonal nature. It is therefore important that they are preserved in season when obtainable in order to ensure their availability throughout the year with their nutritional value still retained [6]. In addition, preservation of fruits and vegetables is of great importance because it makes provision for delayed use, value addition and eliminates wastage [7]. Low-temperature handling and storage have been described as the most important physical method for post-harvest loss control [8]. The temperature of the surrounding air and produce can be reduced by forced air cooling, hydro-cooling, vacuum cooling, and adiabatic cooling [9].

Fruits and vegetables are highly perishable commodities that cannot be kept for a long period due to their perishable nature and, therefore, presents storage difficulties [10]. This study is to assess the storage of fresh fruits and vegetables to reduce some of the postharvest losses and raise the value at the glut period.

Evaporative cooling is a well-known system to cool the environment. This is an adiabatic process, in which ambient air is cooled as a result of transferring its sensible heat to the evaporated water carried with the air. In the evaporative cooled structure, the maximum advantage of the natural environment is taken for lowering down the temperature of outside ambient air to a considerable low level. The evaporative cooling storage system is easy to operate, efficient and affordable most especially for peasant farmers in developing countries like Nigeria where other methods of preservation are quite expensive and unaffordable [11]. 


\section{International Journal of Science and Research (IJSR) \\ ISSN (Online): 2319-7064 \\ Index Copernicus Value (2013): 6.14 | Impact Factor (2014): 5.611}

Evaporative cooling storage structure (ECSS) is a double wall structure having space between the walls which is filled with porous water-absorbing materials called pads [12-14]. These pads are kept constantly moist by applying water. When unsaturated air passes through a soaked pad, transfer of mass and heat takes place and the energy for the evaporation process comes from the air stream. Evaporative cooling is an adiabatic process occurring at constant enthalpy $[15,16]$. This is the most economical way of reducing the temperature by humidifying the air. It has many advantages over refrigeration system, as it does not use refrigerant so it is environmental friendly (reduces $\mathrm{CO}_{2}$ ). It does not make noise as there is no moving part. It does not use electricity so its saves energy. It does not require high initial investment as well as operational cost in design and maintenance. It can be constructed with locally available materials in remote areas and most importantly, it is eco-friendly as it does not need chlorofluorocarbons [17, 18]. Evaporation of moisture from vegetables causes wilting and shriveling resulting in weight loss. The process of evaporative cooling is an adiabatic exchange of heat when ambient air is passed through a saturated surface to obtain low temperature and high humidity, which are desirable for extending the storage life of vegetables [19].

\section{Material and Methods}

\subsection{Materials}

The following materials were selected: Wood (Mahogany and Akwamari), Jute bag, Wire mesh or gauzes wire, Aluminum sheet, Glue, Nail, Thermometer (wet bulb and dry bulb), digital weighing balance, and calibrated bucket. While choosing the materials the following factors were considered as, availability of the materials, suitability of the material under working conditions, cost of materials, strength of the materials, hardness of the materials, malleability, toughness and reaction of the materials with food and water [20].

\subsection{Description of the System}

The storage chamber consists of three trays in the form of drawers where the fruits and vegetables are stored. The trays were constructed from cross netted wire materials (wire mesh) with wooden edges of the storage chamber being accessible from the side of the structure. The structural framework of the system is covered with jute bag which encloses the cooling medium. Water troughs are at the top and bottom of the structure in order to provide water for the continuous wetting of the jute bag by gravity and capillary action. The water troughs were constructed from aluminum sheet. The entire structure sits inside the bottom water trough to facilitate water movement through the jute bag and also to collect water that flows by gravity through the jute bag from the upper water trough as reported by[21].

The storage system works on the principle of evaporative cooling. The process of cooling is based on the principle of heat transfer from the storage chamber through the wet jute bag which causes the evaporation of the water in the jute bag there by cooling the storage chamber. The jute bag is wetted by water from the top and bottom water troughs through gravity and capillary action. Apart from the cooling, the evaporative action results in high relative humidity of the air in the storage chamber, making the atmosphere in the storage chamber more conducive to storage of fruits and vegetables, which prevents the drying out of the fruits and vegetables and therefore extends its shelf life. As long as evaporation takes place the content of the cabinet will be kept at a temperature lower than that of the environment. The trays are rectangular in shape with an area of $3355 \mathrm{~cm}^{2}$ and a volume of $16775 \mathrm{~cm}^{3}$ and thevolume of the top water trough is 26 litres while the lower water trough is 44.6 litres.

\subsection{Theory and basic principle of evaporative cooling system}

Evaporative cooling is a physical occurrence in which evaporation of a liquid, typically surrounding air, cools an object or a liquid in contact with it. When considering water evaporating into air, the wet-bulb temperature, as compared to the air's dry-bulb temperature, is a measure of the potential for evaporative cooling [22]. Evaporation of water produces a considerable cooling effect and the faster the evaporation the greater the cooling. When the temperatures are the same, no net evaporation of water in air occurs, thus there is no cooling effect. The principle of working of this system is "when a particular space is conditioned and maintained at a temperature lower than the ambient temperature surrounding the space, there should be the release of some moisture from outside the body'. This maintains low temperature and elevated humidity in the space compared to the surrounding. This evaporative cool chamber fulfills all these requirements and is helpful to small farmers in rural areas[4].

Evaporative coolers provide cool air by forcing hot dry air over a wetted pad. The water in the pad evaporates, removing heat from the air while adding moisture. When water evaporates, it draws energy from its surroundings, which produced a considerable cooling effect. Cooling occurs when air, that is not too humid, passes over a wet surface; the faster the rate of evaporation the greater the cooling. The efficiency of a cooler depends on the humidity of the surrounding air [22]. Very dry air can absorb a lot of moisture so greater cooling occurs. In the extreme case of air that is totally saturated with water, no evaporation can take place and no cooling occurs. The evaporative cooled storage structures work on the principle of adiabatic cooling caused by evaporation of water, made to drip over the bricks or cooler pads. Generally, an evaporative cooler is made of a porous material that is fed with water. Hot dry air is drawn over the material. The water evaporates into the air raising its humidity and at the same time reducing the temperature of the air. Cooling is provided by the evaporative heat exchange which takes advantage of the principles of the latent heat of evaporation where tremendous heat is exchanged when water evaporates. It makes use of the free latent energy in the atmosphere. The relationship between air and water is shown in the psychometric chart (Fig. 1). Air acts like a sponge to water. The key difference is that as the air increases in temperature it can hold more water.

If the ambient conditions of the air are known, then the amount of cooling can be determined using this chart. For an ideal evaporative cooler, which means, $100 \%$ efficient, the 


\section{International Journal of Science and Research (IJSR) \\ ISSN (Online): 2319-7064 \\ Index Copernicus Value (2013): 6.14 | Impact Factor (2014): 5.611}

dry bulb temperature and dew point should be equal to the wet-bulb temperature [23]). The psychometric chart in Figs. 1 and 2 explain what happens when the air passed through an evaporative unit.

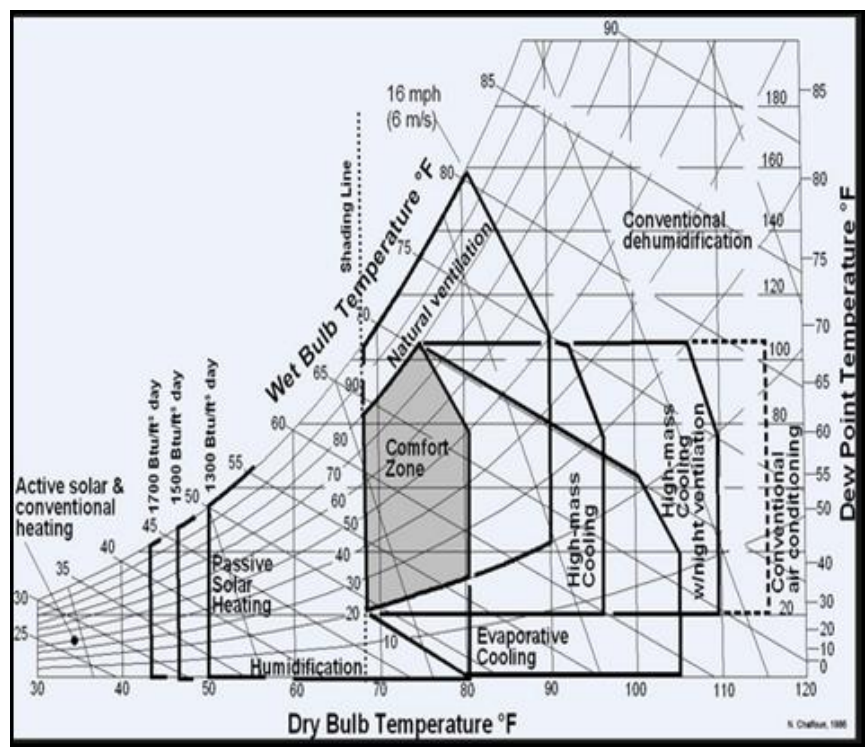

Figure 1: Psychometric chart explaining principle of Evaporating Cooling

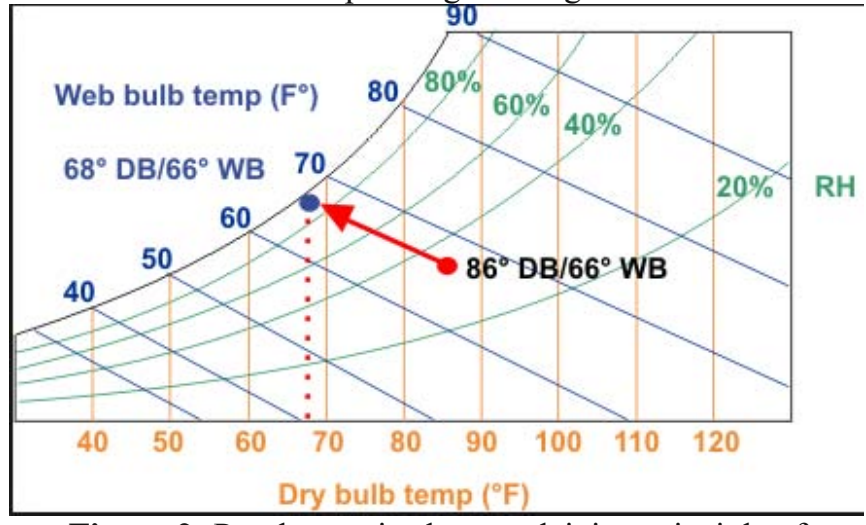

Figure 2: Psychometric chart explaining principle of adiabatic cooling.

\subsection{Per Cent Loss in Weight (PLW)}

Percent loss in weight (PLW) was determined by weighing the vegetables after 8 days interval during storage with the equation used by $[24,25]$.

$$
(P L W)=\frac{W_{1}-w_{2}}{W_{1}} \times 100
$$

$\mathrm{W}_{1}=$ Weight of sample before storage, $\mathrm{Kg}$

$\mathrm{W}_{2}=$ Weight of sample after storage, $\mathrm{Kg}$

\subsection{Methodology}

The developed evaporative cooling system was tested using two samples of fruits and vegetables viz; tomatoes and hot pepper. It was tested for a period of eight days for the tomatoes and hot pepper.

The experiment was carried out at Agricultural Engineering Workshop of Abubakar Tafawa Balewa University Bauchi Nigeria using $4003 \mathrm{~g}$ of fresh Tomatoes and $1056 \mathrm{~g}$ of Hot pepper respectively. The temperature (wet bulb and dry bulb) of the storage chamber was taken under no load condition prior to the introduction of the specimen. The storage chamber was tested for its ability to reduce the temperature while maintaining the increased relative humidity. The evaporative cooling system was tested under load condition to preserve tomatoes and hot pepper for 8 days. During the period of the experiment, the dry bulb and the wet bulb thermometers were suspended in the storage chamber to ascertain the variation of the temperature of the chamber while a control sample of the same quantity were spread on a tray exposed to the open air.

The temperature of the ambient and the evaporative cooling system were recorded twice daily (morning and afternoon) using the wet bulb and dry bulb thermometer.

The weight loss was measured using a digital weighing balance. The weight of the samples was measured daily for the tomatoes and hot pepper until the end of the experiment. The average weight of the samples was determined and the mean change in the weight of the respective fruit and vegetable with time during the storage period was calculated. During the period of the study, a periodic attention was taken to refill the water in the water troughs as the level of the water drop below half of the capacity of the water troughs and the total quantity of water used throughout the period of the experiment was measured using a calibrated bucket which is not within the scope of the study.

\subsection{Selection of Insulating Material}

As part of the general requirements, the efficiency of an active evaporative cooler depends on the rate and amount of evaporation of water from the filling material. This is dependent upon the air velocity, filling material thickness and the degree of saturation of the filling material which is a function of the water flow rate wetting the filling material $[26,27]$. Similar filling materials have been used by $[24,28]$. The ambient and cabinet temperature was measured using a digital thermometer and relative humidity by digital humidity-temperature meter. Products weight (preserved and unpreserved) was determined by digital weight balance. The evaporative cooling system was tested over a period of 8 days using $40 \mathrm{~kg}$ of tomatoes and $15 \mathrm{~kg}$ of hot pepper fruit. The chamber was tested for its suitability to reduce the temperature while maintaining the increased relative humidity. During the testing period, the thermometer was suspended in the chamber through a small hole in the cabinet to ascertain the variation of temperature in the chamber, while a control sample of $40 \mathrm{~kg}$ of tomatoes and $15 \mathrm{~kg}$ of hot pepper fruit spread on a tray exposed to the open air.

\section{Results and Discussion}

\subsection{Temperature and Relative Humidity Variation}

The performance of the evaporative cooling system was evaluated from morning to afternoon at an interval of 1 hour for 8 hours daily to the temperature variations for 8 days for tomatoes and hot pepper as shown in Table 1 and 2. Within these periods of evaluating the performance of the cooling system, theambient temperature kept on increasing with time changing, the cabinet experienced drop in temperature and 


\section{International Journal of Science and Research (IJSR) \\ ISSN (Online): 2319-7064}

Index Copernicus Value (2013): 6.14 | Impact Factor (2014): 5.611

thereafter maintained an appreciable constant lowtemperature value of about $22^{0} \mathrm{C}$ with time for the remaining testing period. However, the average temperature inside the cooling chamber varied from 20 to $23.5^{\circ} \mathrm{C}$ while in the ambient air temperature varied from 25 to $28^{\circ} \mathrm{C}$ for tomatoes and an average of 20.5 to $26.5^{\circ} \mathrm{C}$ inside the Cabinet while in the ambient air temperature was from 28 to $30.5^{\circ} \mathrm{C}$ for hot pepper. Thus, the evaporative cooling system temperatures wereconsistently lower than the ambient air temperatures during the hottest time of the day when insulation was noticeable and cooling most needed also inside the evaporative cooling chamber. Themean relative humidity of cabinet during the period of the experimentwas from 51 to $93 \%$ respectively while the mean relative humidity of the ambient environment was observed from 47 to $58 \%$ for tomatoes and the mean relative humidity for hot pepper was from 49 to $95 \%$ for the cabinet and the mean relative humidity for ambient was from 47 to $57 \%$ as shown in Table 2. These results clearly demonstrate that the evaporative cooling system is useful in the study area climate for shortterm preservation of farm products, especially during the hottest time of the day when cooling is most needed as shown in Fig. 1 and 2 below. The results are in agreement with the findings of $[22,29]$. Previous findings showed that evaporative cooler maintained the temperature between 14.4 and $23.5^{\circ} \mathrm{C}$ and relative humidity between 73 and $92 \%$ during storage periods [30].

Table 1: Relative humidity and Temperature of Cabinet and Ambient for Tomatoes

\begin{tabular}{|c|c|c|c|c|}
\hline Time & $\begin{array}{c}\text { Temp } \\
\text { (Cabinet) }\end{array}$ & $\begin{array}{c}\text { RH } \\
\text { (cabinet) }\end{array}$ & $\begin{array}{c}\text { Temp } \\
\text { (Ambient) }\end{array}$ & $\begin{array}{c}\text { RH } \\
\text { (ambient) }\end{array}$ \\
\hline $8: 00 \mathrm{hr}$ & $23.5^{\circ} \mathrm{C}$ & $51 \%$ & $25.5^{\circ} \mathrm{C}$ & $58 \%$ \\
\hline $9: 00 \mathrm{hr}$ & $22.5^{\circ} \mathrm{C}$ & $52 \%$ & $25^{\circ} \mathrm{C}$ & $54 \%$ \\
\hline $10: 00 \mathrm{hr}$ & $22^{0} \mathrm{C}$ & $56 \%$ & $28^{0} \mathrm{C}$ & $49 \%$ \\
\hline $11: 00 \mathrm{hr}$ & $21^{0} \mathrm{C}$ & $65 \%$ & $27.5^{0} \mathrm{C}$ & $48 \%$ \\
\hline $12: 00 \mathrm{hr}$ & $21^{0} \mathrm{C}$ & $67 \%$ & $28^{0} \mathrm{C}$ & $47 \%$ \\
\hline $13: 00 \mathrm{hr}$ & $21^{\circ} \mathrm{C}$ & $81 \%$ & $27^{0} \mathrm{C}$ & $49 \%$ \\
\hline $14: 00 \mathrm{hr}$ & $20^{\circ} \mathrm{C}$ & $83 \%$ & $27^{0} \mathrm{C}$ & $50 \%$ \\
\hline $15: 00 \mathrm{hr}$ & $20^{\circ} \mathrm{C}$ & $90 \%$ & $26.5^{0} \mathrm{C}$ & $51 \%$ \\
\hline $16: 00 \mathrm{hr}$ & $20^{\circ} \mathrm{C}$ & $93 \%$ & $25^{\circ} \mathrm{C}$ & $56 \%$ \\
\hline
\end{tabular}

Table 2: Relative humidity and Temperature of Cabinet and Ambient for Hot Pepper

\begin{tabular}{|c|c|c|c|c|}
\hline TIME & $\begin{array}{c}\text { Temp. } \\
\text { (Cabinet) }\end{array}$ & $\begin{array}{c}\text { RH } \\
\text { (cabinet) }\end{array}$ & $\begin{array}{c}\text { Temp. } \\
\text { (Ambient) }\end{array}$ & $\begin{array}{c}\text { RH } \\
\text { (Cabinet) }\end{array}$ \\
\hline $8: 00 \mathrm{hr}$ & $26.5^{\circ} \mathrm{C}$ & $49 \%$ & $28.5^{0} \mathrm{C}$ & $57 \%$ \\
\hline $9: 00 \mathrm{hr}$ & $25^{\circ} \mathrm{C}$ & $56 \%$ & $28^{0} \mathrm{C}$ & $55 \%$ \\
\hline $10: 00 \mathrm{hr}$ & $24^{0} \mathrm{C}$ & $58 \%$ & $31^{0} \mathrm{C}$ & $49 \%$ \\
\hline $11: 00 \mathrm{hr}$ & $23.5^{\circ} \mathrm{C}$ & $67 \%$ & $30.5^{\circ} \mathrm{C}$ & $48 \%$ \\
\hline $12: 00 \mathrm{hr}$ & $22.5^{0} \mathrm{C}$ & $72 \%$ & $31^{\circ} \mathrm{C}$ & $47 \%$ \\
\hline $13: 00 \mathrm{hr}$ & $21^{0} \mathrm{C}$ & $82 \%$ & $30^{0} \mathrm{C}$ & $50 \%$ \\
\hline $14: 00 \mathrm{hr}$ & $21^{0} \mathrm{C}$ & $84 \%$ & $30^{0} \mathrm{C}$ & $52 \%$ \\
\hline $15: 00 \mathrm{hr}$ & $20.5^{\circ} \mathrm{C}$ & $92 \%$ & $29.5^{\circ} \mathrm{C}$ & $53 \%$ \\
\hline $16: 00 \mathrm{hr}$ & $20.5^{\circ} \mathrm{C}$ & $95 \%$ & $28^{0} \mathrm{C}$ & $56 \%$ \\
\hline
\end{tabular}

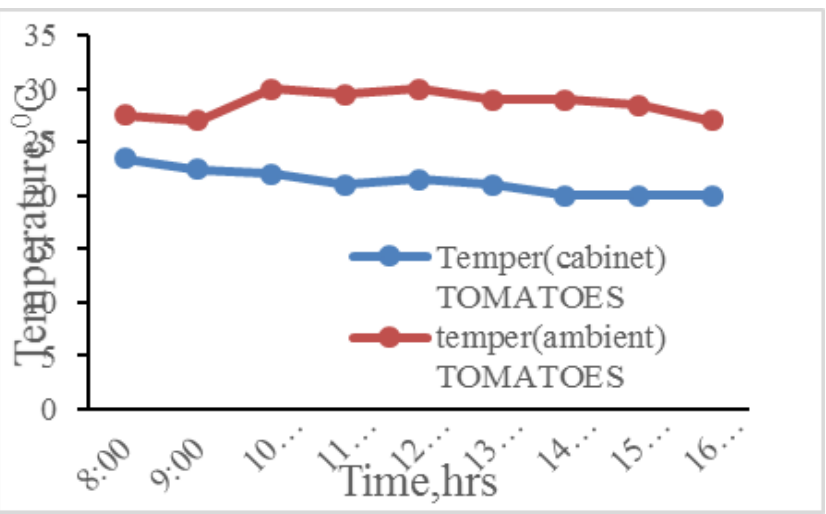

Figure 1: Temperature of Cabinet and Ambient condition against time for Tomatoes

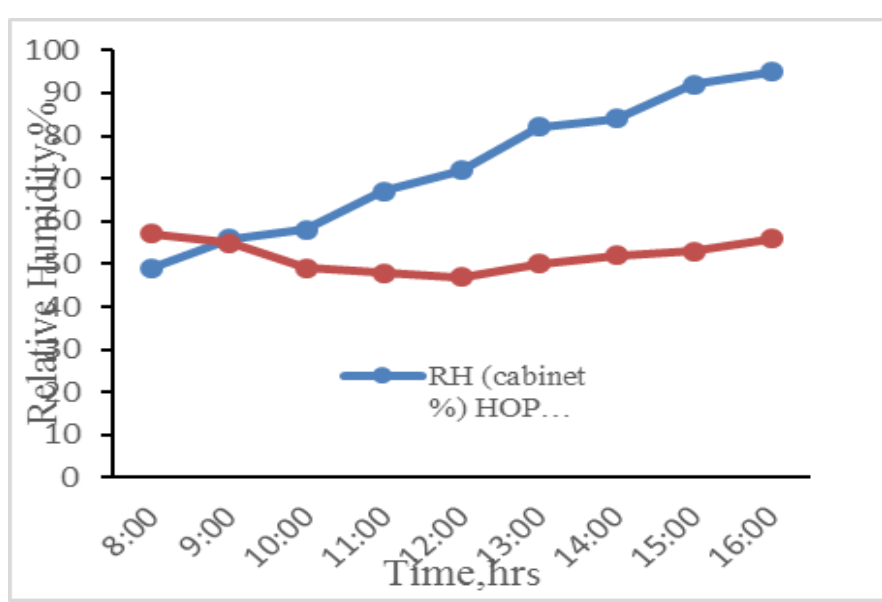

Figure 2: Relative humidity of Ambient and Cabinet over Time for Hot Pepper

\subsection{Effect of Temperature and Relative humidity on the Shelf life of Vegetables.}

The performance of the evaporative cooling system at a storage period of 8 days for the tomatoes and hot pepper was achieved as against the 3 days for the ambient storage. During the experiment, rotting was started to observe at 3 days of storage for the samples kept in the ambient environment while rotting was started to be observed at 8 days of storage for the samples kept inside the cabinet cooler, as shown in Figure 3. LalBasediya et al., and Mogaji and Fapetu, [22, 29] also observed that the storage of these vegetables are within their findings and it was observed that the weight loss of tomatoes and hot pepper were minimum when the commodities were stored in the evaporative cooling system chamber while it was maximum in ambient storage as presented in Table 3 and 4. The physiological weight loss obtained for the tested samples that is, tomatoes and hot pepper are plotted in Figures 3 and 4 respectively. The weight of tomatoes stored in open air was maintained for only 8 days after which there was a sharp decline in weight from approximately 40.00 to $15.453 \mathrm{~kg}$ and hot pepper 15.00 to $10.117 \mathrm{~kg}$ for the tested samples respectively after 8 days of storage, resulting into a loss in weight of about 24.547 and 4.883 kgfor the samples respectively. Contrary to this observation, tomatoes, and hot pepper kept in the evaporative cooling cabinet had their weight relatively maintained at 39 and $15 \mathrm{~kg}$ within one weekof storage with only an approximate 2.95 and $1.138 \mathrm{~kg}$ loss in weight for the tested samples respectively after 8 daysof storage. 


\section{International Journal of Science and Research (IJSR) \\ ISSN (Online): 2319-7064}

Index Copernicus Value (2013): 6.14 | Impact Factor (2014): 5.611

Table 3: Weight loss in Tomato $(\mathrm{Kg})$

\begin{tabular}{|c|c|c|}
\hline Days & Cabinet & Ambient \\
\hline 1 & $40.000 \mathrm{Kg}$ & $40.000 \mathrm{Kg}$ \\
\hline 2 & $39.783 \mathrm{Kg}$ & $35.833 \mathrm{Kg}$ \\
\hline 3 & $39.075 \mathrm{Kg}$ & $31.183 \mathrm{Kg}$ \\
\hline 4 & $38.694 \mathrm{Kg}$ & $26.946 \mathrm{Kg}$ \\
\hline 5 & $38.145 \mathrm{Kg}$ & $22.314 \mathrm{Kg}$ \\
\hline 6 & $37.647 \mathrm{Kg}$ & $19.967 \mathrm{Kg}$ \\
\hline 7 & $37.054 \mathrm{Kg}$ & $15.453 \mathrm{Kg}$ \\
\hline
\end{tabular}

Table 4:Weight loss in Hot pepper $(\mathrm{Kg})$

\begin{tabular}{|c|c|c|}
\hline Days & Cabinet & Ambient \\
\hline 1 & $15.000 \mathrm{Kg}$ & $15.000 \mathrm{Kg}$ \\
\hline 2 & $15.653 \mathrm{Kg}$ & $14.427 \mathrm{Kg}$ \\
\hline 3 & $15.257 \mathrm{Kg}$ & $12.877 \mathrm{Kg}$ \\
\hline 4 & $14.473 \mathrm{Kg}$ & $12.134 \mathrm{Kg}$ \\
\hline 5 & $13.704 \mathrm{Kg}$ & $11.985 \mathrm{Kg}$ \\
\hline 6 & $13.529 \mathrm{Kg}$ & $11.132 \mathrm{Kg}$ \\
\hline 7 & $13.862 \mathrm{Kg}$ & $10.117 \mathrm{Kg}$ \\
\hline
\end{tabular}

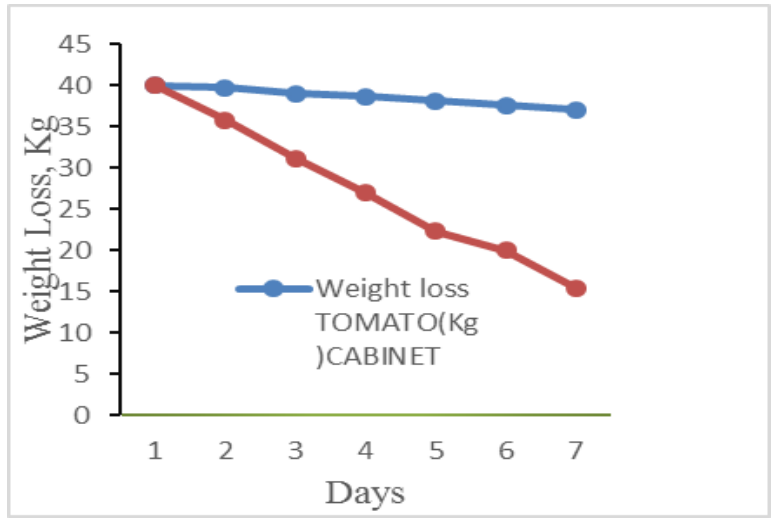

Figure 3: Weight loss of Tomatoes $(\mathrm{Kg})$

The intensity of weight loss during storage depends on maturity stage [31]. Weight lose of fresh tomatoes is primarily due to transpiration and respiration. Cold stored fruits have low weight loss due to temperature effects on vapor pressure difference and increased water retention.

Rab et al.,[32] reported that the weight loss of tomato fruit is significantly affected by harvest stages. This finding is in accordance with the work done by Moneruzzaman et al.,[31] who reported that storage of tomato at low temperature and high relative humidity decrease the early deterioration percentage.

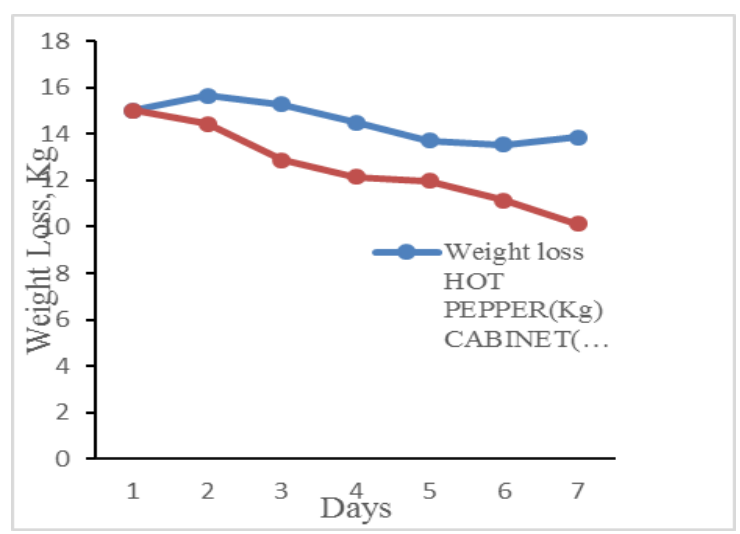

Figure4:Weight loss of Hot Pepper (Kg)
The higher percentage weight loss in pepper stored at ambient conditions compared to those stored in the evaporative cooler appeared to be related to the $\mathrm{RH}$ and temperature surrounding the produce. The evaporative cooler had more air humidity as well as cooler than the ambient storage conditions, thereby capable of reducing excessive moisture loss from the produce as observed by Samira et al., [33]. The types of surfaces and underlying tissues of fruit may also have a marked effect on the rate of water loss [34] which could be seen as reasons for the differences observed.

\section{Conclusion}

Nigeria is one of the humid countries in the world. Produce goes waste due to improper post-harvest operations and lack of enough storage facilities. The evaporative cooling system has a very large potential to provide thermal comfort. Today, the evaporative cooling storage system is increasingly being used for on-farm storage of fruits and vegetables. The evaporative cooling system not only lowers the air temperature surrounding the produce, it also increases the moisture content of the air. Thishelps prevent the drying amount of the produce, therefore, extends the shelf life of the produce. The evaporative cooling system is well suited where; temperatures are high, humidity is low, water can be spared for this use, and air movement is available. The shelf life of tomatoes and pepper stored in the evaporative cooler was effectively improved compared with storage under ambient condition. The result also showed that maintaining lower temperature and higher relative humidity during storage combined with selecting cultivars having long shelf life could maintain fruit quality and reduce loss. Quality attributes were found to be best which was stored in the evaporative cooler

\section{References}

[1] A. I. Ihekoronye and P. O. Ngoddy, Integrated food science and technology for the tropics: Macmillan, 1985.

[2] R. Hanif, Z. Iqbal, M. Iqbal, S. Hanif, and M. Rasheed, "Use of vegetables as nutritional food: role in human health," Journal of Agricultural and Biological Science, vol. 1, pp. 18-20, 2006.

[3] E. M. G. Peter, "Vegetables Virtures: "Nutritional Values",

Hppt://www.angr.umd.edu/howard/mg/advege.htm pp. 1-6, 1997

[4] S. M. Dadhich, H. Dadhich, and R. Verma, "Comparative study on storage of fruits and vegetables in evaporative cool chamber and in ambient," International Journal of Food Engineering, vol. 4, 2008.

[5] A. Dzivama, "Performance evaluation of an active cooling system for the storage of fruits and vegetables," Ph. D. Thesis, Department of Agricultural Engineering, University of Ibadan, Ibadan Nigeria. 2000. In proceeding of Nigeria Institution of Agricultural Engineering, 2013.

[6] CFNEU, "Community Food and Nutrition Extension Unit"." D-II /183, Kidwai Nagar (West).N.Delhi-110023 511.http://wed.nic.in/us5.htm, 2003.

[7] O. Aremu, "Storage and Preservation of Fruits and Vegetable in Nigeria " First National Seminar on Fruits 


\section{International Journal of Science and Research (IJSR) \\ ISSN (Online): 2319-7064}

Index Copernicus Value (2013): 6.14 | Impact Factor (2014): 5.611

and Vegetables vol. Caxton Press (West Africa) Limited, pp. 121-126, 1975

[8] T. Seyoum and K. Woldetsadik, "Natural ventilation evaporative cooling of mango," J. Agric. Biotechnol. Environ, vol. 2, pp. 1-5, 2000.

[9] J. F. Thompson, F. G. Mitchell, and T. R. Rumsay, Commercial cooling of fruits, vegetables, and flowers: UCANR Publications, 2008.

[10]CFNEU, "Community Food and Nutrition Extension Unit"," D-II /183, Kidwai Nagar(West).N.Delhi-110023 511.http://wed.nic.in/us5.htm., 2003.

[11]A. I. Ihekoronye and P. O. Ngoddy, Integrated food science and technology for the tropics: Macmillan, 1985.

[12] R. Hanif, Z. Iqbal, M. Iqbal, S. Hanif, and M. Rasheed, "Use of vegetables as nutritional food: role in human health," Journal of Agricultural and Biological Science, vol. 1, pp. 18-20, 2006.

[13]E. M. G. Peter, "Vegetables Virtures: "Nutritional Values"'

Hppt://www.angr.umd.edu/howard/mg/advege.htmpp. $1-6,1997$

[14]S. M. Dadhich, H. Dadhich, and R. Verma, "Comparative study on storage of fruits and vegetables in evaporative cool chamber and in ambient," International Journal of Food Engineering, vol. 4, 2008.

[15]A. Dzivama, "Performance evaluation of an active cooling system for the storage of fruits and vegetables," $\mathrm{Ph}$. D. Thesis, Department of Agricultural Engineering, University of Ibadan, Ibadan Nigeria. 2000. In proceeding of Nigeria Institution of Agricultural Engineering, 2013.

[16] CFNEU, "Community Food and Nutrition Extension Unit"." D-II /183, Kidwai Nagar (West).N.Delhi-110023 511.http://wed.nic.in/us5.htm, 2003.

[17] O. Aremu, "Storage and Preservation of Fruits and Vegetable in Nigeria " First National Seminar on Fruits and Vegetables vol. Caxton Press (West Africa) Limited, pp. 121-126, 1975

[18] T. Seyoum and K. Woldetsadik, "Natural ventilation evaporative cooling of mango," J. Agric. Biotechnol. Environ, vol. 2, pp. 1-5, 2000.

[19] J. F. Thompson, F. G. Mitchell, and T. R. Rumsay, Commercial cooling of fruits, vegetables, and flowers: UCANR Publications, 2008.

[20]CFNEU, "Community Food and Nutrition Extension Unit"," D-II /183, Kidwai Nagar (West).N.Delhi-110023 511.http://wed.nic.in/us5.htm., 2003.

[21] K. Vala, F. Saiyed, and D. Joshi, "Evaporative Cooled Storage Structures: An Indian Scenario," 2014.

[22]S. Jha and S. Kudos, "Determination of physical properties of pads for maximizing cooling in evaporative cooled store," Journal of Agricultural Engineering, vol. 43, pp. 92-97, 2006.

[23] S. Roy and D. Khurdiya, "Studies on evaporatively cooled zero energy input cool chamber for storage of horticultural produce," Indian Food Packer, vol. 40, pp. 26-31, 1986.

[24]R. Singh and K. Satapathy, "Performance evaluation of zero energy cool chamber in hilly region," Agricultural Engineering Today, vol. 30, pp. 47-56, 2006.

[25] K. Vala and D. Joshi, "Development of Evaporative Cooling Transportation System for Perishable

Commodities," Journal of Agricultural Engineering, vol. 47, pp. 27-33, 2010.

[26] E. V. Gómez, F. R. Martínez, and A. T. González, "The phenomenon of evaporative cooling from a humid surface as an alternative method for air-conditioning," Journal homepage: www. IJEE. IEEFoundation. org, vol. 1, pp. 69-96, 2010.

[27] S. Jha, "Development of a pilot scale evaporative cooled storage structure for fruits and vegetables for hot and dry region," JOURNAL OF FOOD SCIENCE AND TECHNOLOGY-MYSORE, vol. 45, pp. 148-151, 2008.

[28] Anonymous,

"NationalHorticultureBoard(NHB),AgriculturalMinistry, Govt.ofIndia," 85institutionalareasection-18 Gurgaon$122015,2015$.

[29] R. Khurmi and J. Gupta, A textbook of Refrigeration and Air Conditioning: S. Chand, 2006.

[30]R. Kenghe, A. Magar, and K. Kenghe, "Design, Development and Testing of Small Scale Mechanical Fruit Washer."

[31] A. lal Basediya, D. Samuel, and V. Beera, "Evaporative cooling system for storage of fruits and vegetables-a review," Journal of food science and technology, vol. 50, pp. 429-442, 2013.

[32] J. R. Camargo, "Evaporative cooling: water for thermal comfort," Ambiente \& Água-An Interdisciplinary Journal of Applied Science, vol. 3, pp. 51-61, 2008.

[33]W. A. Olosunde, J. Igbeka, and T. O. Olurin, "Performance evaluation of absorbent materials in evaporative cooling system for the storage of fruits and vegetables," International Journal of Food Engineering, vol. 5, 2009.

[34]R. Wijeratnam, V. Pierisl, I. Hewajulige, and N. Amarasinghe, "Development of low cost storage system for extending storage life of lime, tomato, mango and papaya," CARP, CompetitiveContract Research Grants Programme: Proceedings, Presentations of Completed Research Projects, 2005, p. 14, 2005.

[35]F. Wiersma, "Evaporative Cooling in Ventilation of Agricultural Structures," An America Society of Agricultural Engineers. Monograph 6th Series, Michigan, USA, 1983.

[36]B. Thakur and D. Dhingra, "Parameters influencing the saturation efficiency of an evaporative cooler," Journal of research-Punjab Agricultural University, 1983.

[37] S. C. Mule, "Studies on development and performance evaluation of on-farm evaporative cooler for storage of sapota fruits," Unpublished Thesis, 2009

[38] T. S. Mogaji and O. P. Fapetu, "Development of an evaporative cooling system for the preservation of fresh vegetables," African Journal of Food Science, vol. 5, pp. 255-266, 2011.

[39] M. Melkamu, T. Seyoum, and K. Woldetsadik, "Effects of pre-and post harvest treatments on changes in sugar content of tomato," African Journal of Biotechnology, vol. 7, 2008.

[40] K. Moneruzzaman, A. Hossain, W. Sani, M. Saifuddin, and M. Alenazi, "Effect of harvesting and storage conditions on the post harvest quality of tomato (Lycopersicon esculentum Mill) cv. Roma VF," Australian Journal of Crop Science, vol. 3, pp. 113-121, 2009.

\section{Volume 5 Issue 1, January 2016}

www.ijsr.net 


\section{International Journal of Science and Research (IJSR) \\ ISSN (Online): 2319-7064}

Index Copernicus Value (2013): 6.14 | Impact Factor (2014): 5.611

[41] A. Rab, H. Rehman, I. Haq, M. Sajid, K. Nawab, and K. Ali, "HARVEST STAGES AND PRE-COOLING INFLUENCE THE QUALITY AND STORAGE LIFE OF TOMATO FRUIT," JAPS, Journal of Animal and Plant Sciences, vol. 23, pp. 1347-1352, 2013.

[42] A. Samira, K. Woldetsadik, and T. S. Workneh, "Postharvest quality and shelf life of some hot pepper varieties," Journal of food science and technology, vol. 50, pp. 842-855, 2013.

[43] R. H. Wills, T. Lee, D. Graham, W. McGlasson, and E. Hall, Postharvest. An introduction to the physiology and handling of fruit and vegetables: Granada., 1981.

\section{Authors Profile}

Bala Gambo Jahun received B.Eng. and M.Eng. degrees in Agricultural Engineering from Abubakar Tafawa Balewa University Bauchi, Nigeria and Modibbo Adama University of Technology, Yola Nigeria in 2004 and 2012, respectively. He is an academic staff at Abubakar Tafawa Balewa University Bauchi, Nigeria and a PhD student at Universiti Putra Malaysia. His research area is on Soil and Machine dynamics.

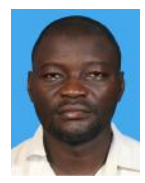

Abdulkadir Salihu Ahmed received the Bachelor of Engineering and Masters of Engineering degrees in Agricultural and Environmental Engineering from Federal University of Technology Yola Nigeria in 2004 and 2013, respectively. During 2007-date, he is

an academic staff with department Agricultural and Bioenvironmental Engineering with Adamawa State Polytechnic Yola Nigeria, he is now a $\mathrm{PhD}$ candidate in Universiti Putra Malaysia undergoing a research in Agricultural Automation and Mechanization. 